\title{
Corporate Governance and Firm Performance: The Role of the Board and Audit Committee
}

\author{
Netai Kumar Saha (Corresponding Author) \\ Senior Lecturer, Dept. of Business Administration \\ East West University, Dhaka-1212, Bangladesh \\ E-mail: netaish006@gmail.com \\ Rehnuma Hoque Moutushi \\ Lecturer, Dept. of Business Administration \\ East West University, Dhaka-1212, Bangladesh \\ Mohammad Salauddin \\ Graduate Student, Dept. of Business Administration \\ East West University, Dhaka-1212, Bangladesh
}

Received: April 1, 2018 Accepted: May 3,2018 Published: June 1, 2018

doi:10.5296/ajfa.v10i1.12933 URL: https://doi.org/10.5296/ajfa.v10i1.12933

\begin{abstract}
Corporate Governance (CG) has become a paramount issue due to its greater significance of practicing accuracy, maintaining accountability, establishing effective internal control and regulating organizations for achieving organizational goals. The study is conducted to explore the relationship between corporate governance and firm performance with considering the role of board and audit committee. The multiple liner regression analysis is used as the underlying statistical test on the dependent variables, ROA, ROE and TQ to test the association between the independent variables (board size, board independence, size of audit committee and audit committee composition) with firm performance. Homogeneous purposive sampling has been used. The sample size of the study is 81 listed companies in DSE. The results of the study signify that board independence ratio and audit committee is statistically significant and has positive impact on ROA and TQ. But it is not statistically significant in the case of firm performance indicator ROE in this study. In addition to, Board size is not statistically significant and has negative correlation with firm performance due to group dynamics, communication gaps and indecisiveness of larger groups.
\end{abstract}

Keywords: Corporate Governance, Firm Performance, Board Size, Board Independence and Audit Composition 


\section{Introduction}

At present, Corporate Governance (CG) has become a topical issue of global concern because of its significant contribution to the economic growth of a nation. Sound corporate governance gives assurance to the investor of providing transparent disclosure and relevant information that are investor-friendly (Okiro, Aduda and Omoro, 2015). Good corporate governance minimizes the risk of bankruptcy (Shleifer and Vishny, 1997). In absence of good CG, many well-performing companies have faced a tremendous downfall across the world. Existing literature suggests that good corporate governance has a significant positive influence on organizational performance (OECD, 2009; Moxey and Berendt, 2008; Gompers et al., 2003; Claessens et al., 2002).

Corporate Governance has been defined by scholars from several points of view. According to Metrick and Ishii (2002), Corporate Governance refers to the commitment to the actual return of the invested capital and it also describes the process of operating an organization. Similarly, Magdi and Nadereh (2002) stated that good CG ensures that an organization is running well and making fair rate of return for investors. CG gives a vivid description of the systems and structure in order to observe managers of higher positions so that they can efficiently manage the organizations. The topic of Corporate Governance had come under the spotlight in the mid-1990s. According to Cadbury Committee (1992), corporate governance is the process by which organizations can be directed and appropriately controlled.

Corporate Governance is defined as the framework for monitoring, regulating and controlling of organizations which permit to exercise the mechanisms of internal and external alternative for achieving the organizational goals. The internal mechanism consists of managerial ownership, board composition and individual and institutional shareholders. On the contrary, the market for corporate control, the statutory audit and the evaluation of stock market are included in the external mechanism (Keasey and Wright, 1993). In other sense, corporate governance refers to the relationship among the directors, corporate managers and shareholders. It also concerned about the relationship of the organization to the stakeholders and the society. Corporate governance more widely describes the combination of laws, listing rules, regulations and practices of private sectors that make the organization capable of attracting capital, give an efficient performance, generate revenue and meet societal expectation legal obligation (Yasser, 2011).

The performance of an organization and its financial decisions are severely affected by the agency conflict between a company's management and the company's stockholders. To solve this issue, the role of corporate governance is very much noteworthy. Corporate governance increases the effectiveness of companies with the association of enough control and supervision. It also has importance in managing the interest of stakeholders and managers to minimize the agency conflicts (Shleifer and Vishny, 1997). Maintaining good corporate governance leads an organization towards achieving its ultimate goals and this is the actual reason for which corporate governance is attaining significant attention now (Shil et al., 2017).

Previous empirical studies (Drobetz et al., 2003; Byrd and Hickman, 1992; Brickley et al., 
1994; Williams, 2000; Rajan and Zingale, 1998; Hossain et al., 2000; Rosenstein and Wyatt, 1990; Hermalin, 1988; Gemmill and Thomas, 2004) have mentioned positive correlation between corporate governance and better firm performance. On the contrary, very few studies (Hutchinson, 2002; Bathala and Rao, 1995) found no association between corporate governance and better firm performance. In spite of these contradictory results, the researchers argue that there is no doubt that maintaining good corporate governance increases the firm's performance. Some major characteristics of the corporate governance are board size, board composition, board independence, audit committee and whether the position of board chairman is given to the CEO role (Kyereboah and Biekpe, 2008).

The issue of corporate governance has become essential in the present situation because of increasing fraudulent activities, agency conflicts and insider trading which weaken the corporate performance (Enobakhare, 2010). In recent time, the downfall of Enron in 2001, the Bank of Credit and Commerce International (BCCI), World.Com in 2002 (Okiro, Aduda and Omoro, 2015) and Hallmark and BASIC bank Scandals in banking sector of Bangladesh (Shil et al., 2017)) are the noteworthy example of corporate failure because of less efficiency of corporate governance. There are some other problems such as inconsistent accounting standards, weak regulatory systems and weak accounting practices. Again inefficiency in boards of directors, poor management of capital markets and little concentration on the minority stockholders interest have a negative influence on corporate governance (World Bank, 2000).

Most of the researches have been conducted in the developed countries but the application of the results and finding may not be applicable for the developing countries like Bangladesh loctating in South East Asia. Very few researches have conducted to find the nexus between corporate governance and firms performances. Some existing studies used a small set of samples, whereas a large set of samples are used in this study which includes 81 listed financial organizations at the Dhaka Stock Exchanges. Therefore this study is intended to answer two research questions; what is the role of board size and the board independence to enhance the firm's financial performance? And how do the audit committee and its composition contribute to enhance better corporate performance?

\section{Literature Review}

\subsection{Corporate Governance and Firm Performance}

There are many accepted definition of corporate governance; On the basis of a framework and cultural condition of a country the definition of CG varies (Armstrong and Sweeney, 2002). In the 1980s the term "corporate governance" came under focus to vividly describe the principles of directing and controlling of business and management of an organization (Bozec 2005). O. Donovan (2003) defines corporate governance as a system of covering the policies and process which manages the shareholders and other stakeholders needs by their management activities with well performing of business, integrity and objective. In other sense, it can be defined as the legal, moral and ethical values of an organization in order to protect the interest of shareholders. 
The purpose of corporate governance is to manage the interest of the shareholders and other stakeholders of an organization. The concept of corporate governance can be applied especially to the listed companies where the significant portion of the shareholders cannot participate in management functions. Although this concept can also be applied to other types of organizations like firms with very few owners, partner-owned firms and also privately owned organizations where ownership are transferred through inheritance generation after generation(Ahmed, Alam, Jafar \& Zaman 2008).

The research is mainly conducted on the theory of agency conflicts which is evaluated to describe the nexus between the principals and the agents. The board members are elected to manage the company by the shareholders at ACM who are also the owners as well. Himmelberg et al. (2002) stated that corporate governance and performance of an organization is driven by some common characteristics which are not exactly measurable and observable. Managers are intended to retain a significant portion of ownership of the high growth firms to give importance to their commitment and utilization of remuneration based on equity; based on stable performance insider ownership gradually increases. Cremers and Nair (2005) found that internal corporate governance and external corporate governance have a positive relationship with organizational performance.

\subsection{Board Size and Firm Performance}

Board Size is the most discussed attribute of CG in the literature. Enobakhare (2010) defined board size as the total number of board members that a company has in its board structure. The functions and performance of a board are influenced by the number as well as the quality of the directors in any organization. Previous studies showed both positive and negative association between board size and firm's performance.

Most of the studies indicated that a large board size affects organizational performance when it is not conclusive. Because the probability of large board size has the opportunity of having better skills and knowledge at their settlement that will increase performance (Williams, 2002). On the contrary, it was argued that when boards become large, they gradually lose their efficiency Ramano et al. (2012). According to Jensen (1993), massive board size has the possibility to create a reduced sense of the responsibility of an individual. It also might be more attached to the problems of bureaucracy. Another prominent scholar Kajola (2002) has the belief that small board size can improve the performance of an organization to a particular level and it is because the improvement done by larger boards of enhanced controlling becomes less effective because of weaker communication and indecisiveness of larger groups. Some research put emphasis on the relationship between board size and organizational performance. It was found that small board size is more suitable for better firm performance and small board size is positively correlated with it (Sanda et al., 2003). Similarly, (Lipton and Lorsch, 1992, Coles et al., 2007 and Pathan et al., 2007) concluded smaller board size is more effective than large board size.

Another major issue which is found in research that larger board size causes some problems such as group dynamics, gaps in communication, the rise of coordination cost, poor firm performance etc. (Dey and Chauhan 2009). There are also counter-arguments. It was revealed 
that in case of proper monitoring and advising functions larger boards have more efficiency than small board size. More value is created for an organization if board size is larger (Andres and Vallelado 2008; Chen et al., 2006). According to the report of Spencer Stuart Board Index (2008), it was shown that a continued trend was going towards smaller boards. Again that report also indicated that board size has also been shrinking over the years. On the contrary, it was also proved that a genuine relationship exists between the performance of firms and size of the board. This relationship is made on the basis of the utilization of Tobin's Q as a performance indicator for BHC (Bank Holding companies) (Belkhir 2004; Adams and Mehran 2005).

A large number of studies put a focus on the fact that there is no significant correlation between board size and firm performance (Busta, 2007; Zulkafli \& Samad 2007; Shelash Al-Hawary; 2011; Staikouras et al., 2007 and Trabelsi, 2010) oppose to the previous argument and they indicated that larger board size does not have any positive influence on firm's performance. Cornett et al., (2009) puts another counter-argument that indeed if the size of the boards is large those are positively associated with corporate performance. It was concluded that a larger board is more desirable and demanding for bank holdings structures and activities. Ramano et al; (2012) stated if the board size can be increased with additional directors having supplementary directorships that will be helpful to add value.

\section{H1: The board size has positive relation on firm performance.}

\subsection{Board Independence and Firm Performance}

The necessity of independent board directors in composition of a board is very much significant for several reasons. Firstly, they are considered as real monitors. Secondly, they have strong capability of management and maintaining discipline. Thirdly, they can play very much effective role to increase organizational performance (Duchin et al., 2010). Again Rhodes et al., (2000) sated that independent directors have financial freedom and hardly have to face the possible conflicting conditions. They are also able to reduce agency problems and the obstacles in managerial self-interest. Additionally they have the capability to give protection to the interest of shareholders. They have efficiency in performing monitoring and control function in an excellent way in order to align organizational resources for better performance (Kumar and Singh, 2012).

Board composition refers to the total number of directors brought from outside the organization in order to sit on the board (Enobakhare 2010). It was found in some research that board composition has a relationship with good governance. In order to ensure organizational growth and corporate accountability non executive and independent or outside board directors are considered as one of the most important elements (Ramano et al, 2012). On the contrary it was also indicated that superfluous proportion of non executive board directors could hamper or damage the instructor role of boards as executive directors naturalize the transfer of information between directors and management and provide information as well as knowledge which independent directors would find difficult to gather (De Andres and Vallelado,2008). 
There is a counter-argument which includes evidence that organizations committing financial reporting false are more likely to have a weaker board of directors who are dominated by the insiders (Farber, 2005 and Ramano et al., 2012). Some empirical studies on the board composition of directors found some positive effects on the organizational performance as a result of having uncommitted directors on the board of the organizations (Xie et al.,2003, Choi et al, 2007, Abor and Adjasi, 2007, Awan, 2012, and Kumar and Singh, 2012). Xiao-Lan and Zong-Jim (2006), Adams and Ferreira (2009), and Kajola (2002) on the other found that composition of boards with representation of outside uncommitted directors and organizational performance there can hardly be any relationship. This particular consequence was attributed to the lack of selection of the uncommitted directors on their sagacity and experience. It was also added that lack of wisdom, sagacity and proper knowledge, lack of proper skills of organizational affairs such directors would not have the capability to perform their roles in an effective manner (Rahman, Mohamed and Ali, 2006). According to Kaplan (1995), poor corporate performance is very closely associated with the appointment of an outside, independent and uncommitted board director.

Finally, it can be concluded that a mixed result is found about the relationship between organizational performance and the freedom of board from the different perspective. This result was found from most of the empirical studies. There is a very strong recommendation by different countries on the composition of a board and independence in the organizations (Gabrielsson and Huse, 2005). Necessarily those boards which have a lot of uncommitted directors show a kind of elevated efficiency and they function to enhance the organizational performance (Daily \& Dalton, 1993).

\section{H2: Board independence has positive association with firm performance.}

\subsection{Audit Committee and Firm Performance}

Audit committees are most predominant governance mechanism aimed at safeguarding the rights of investors by reducing information asymmetry and providing trustworthy information about the company (Abdul Rahman and Ali, 2006; DeZoort et al., 2002). The audit committee can play a vital role in reducing information asymmetry between corporate managers and providers of finance as financial reporting is the most important mode of communicating the financial performance of a company to stakeholders (Dhaliwal et al., 2006; Krishnan, 2009). Meanwhile, the characteristics of audit committees emerge as salient factor to be considered in contemporary corporate governance research and practice. These characteristics are associated with effective task execution.

In one study, Yige et al. (2012) showed the relation of audit committee meeting and board of director's independence. Audit committee meetings and board of director independence are complementary in corporate governance. Moreover, they find that as audit committees meet more frequently the board independence increases more. Research findings of Xie et al. (2003) indicate that frequent meetings of the audit committee show greater diligence. Research evidence of Raghunandan and Rama (2007) and Sharma et al. (2009) shows that profitability and growth are related in a positive way to audit committee meeting frequency. Moreover, more frequent audit committee meetings are associated with better quality 
financial statements (Abbott et al., 2000; and Beasley et al., 2000).

In another study, a pessimistic relation between audit committee independence and earnings management is observed by Klein (1998), and this finding of the study is similar with the idea that a paucity of independence impairs the ability of boards and audit committees to superintend management. In another study, DeZoort et al. (2002) drew a framework universal four-dimensional (composition, resources, authority and diligence) with respect to benefits and effectiveness of audit committees. According to the study, while the composition reflects independence, the other three relate to the inputs to the corporate governance processes adopted by the firms. From the above, it can be determined that the key purpose of the board's audit committee is to inspect the financial reporting process of a firm. There is a remarkable literature that links independence, size and other characteristics of the board of directors and audit committees in order to improved firm performance and value (Klein, 1998). Increased level of independence and expertise on board and audit committees increase firm value (Chan and $\mathrm{Li}, 2008$ ). The common wisdom is that the level of independence of audit committee members is closely related with improved monitoring of the financial reporting process (Bronson et al., 2009). Independence is often heralded as the single most important board and audit committee characteristic; however, the evidence is somewhat mixed. Bhagat and Black (2001) find no relationship in their study between the ratio of outsider versus insider board members and firm performance. Kirkpatrick (2009) finds that independent members on the audit committees contribute to a higher market value.

Beasley (1996) finds that presence of an audit committee does not affect the likelihood of fraud, but more independent members on the board of directors should decrease the possibility of fraud. How-ever, Abbott et al. (2004) ensured that an audit committee consisting of independent members and who meet minimum twice a year decreases the probability that the firm will be associated with misleading reporting.

\section{H3: The audit committee size has positive relation on firm performance.}

H4: The presence of independent directors on audit committee has positive relation on firm performance.

\section{Methodology of the study}

The study is mainly conducted by deriving data from the secondary sources by using sample size of 81 listed companies in DSE. Data has been collected from published annual reports, company websites and sever other sources. 5 years data ranging from the period of 2013 to 2017 has been considered to conduct the study. Homogeneous purposive sampling has been used for the selection of sample size. The sample includes all the listed companies from banking industry (30), financial institutions (23), fuel and power industry (18), IT sector (8) and telecommunication (2).

\subsection{Model Specification}

For the purpose of empirical analysis, the multiple liner regression analysis is used as the underlying statistical test on the dependent variables, ROA, ROE and TQ to test the 


\section{Macrothink}

association between the independent variables (board size, board independence, size of audit committee and audit committee composition) with firm performance.

The conceptual model of the study is presented below:

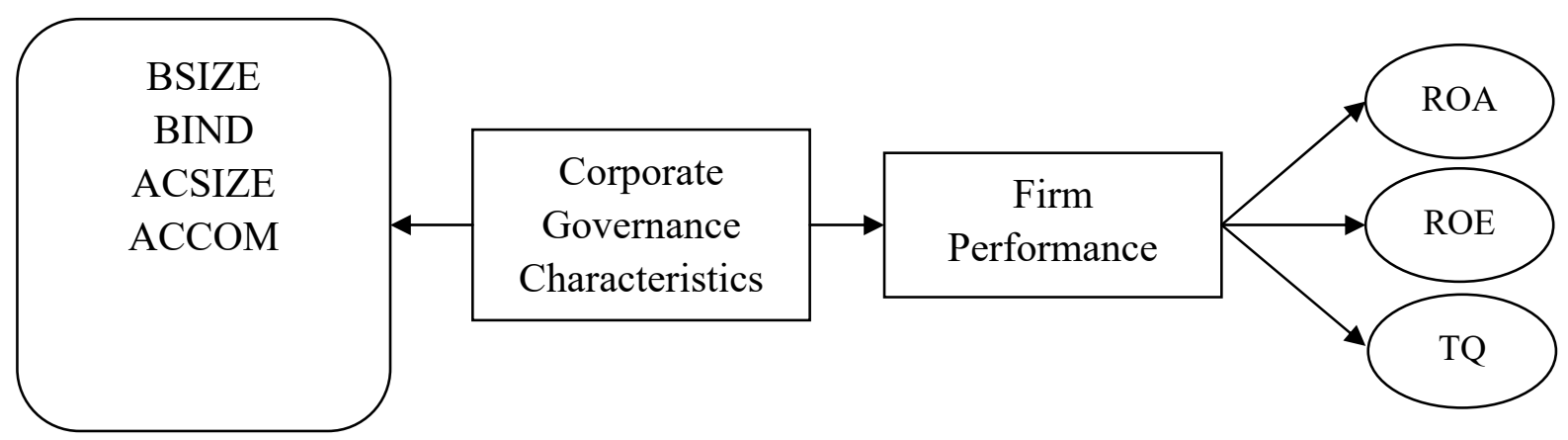

Source: Conceptual Framework of the Anglo American Model

The following regression models are developed to test the relationship between corporate governance variables and firm performance.

$$
\begin{gathered}
\mathbf{F P}_{-} \mathbf{R O E}=\alpha+\beta \text { BSIZE }+\beta 2 \mathrm{BIND}+\beta 3 \mathrm{ACSIZE}+\beta 4 \mathrm{ACCOM}+\varepsilon \\
\mathbf{F P}_{-} \mathbf{R O A}=\alpha+\beta \quad \mathrm{BSIZE}+\beta 2 \mathrm{BIND}+\beta 3 \mathrm{ACSIZE}+\beta 7 \mathrm{ACCOM}+\varepsilon \\
\mathbf{T Q}=\alpha+\beta \text { BSIZE }+\beta 2 \mathrm{BIND}+\beta 3 \mathrm{ACSIZE}+\beta 7 \mathrm{ACCOM}+\varepsilon
\end{gathered}
$$

The following table shows the corporate governance variables and their description in this study. 


\section{Macrothink}

Table 1. Variables, definition and measurement

\begin{tabular}{|c|c|c|}
\hline Variables & Description & Measurement \\
\hline \multicolumn{3}{|c|}{ Performance Measures } \\
\hline ROA & Return on Asset & $\begin{array}{l}\text { Net profit after tax and provision divided by the } \\
\text { total asset at the end of each year }\end{array}$ \\
\hline ROE & Return on Equity & $\begin{array}{l}\text { Net profit after tax and provision divided by the } \\
\text { total equity as at the end of each year }\end{array}$ \\
\hline TQ & Tobin's Q & $\begin{array}{l}\text { Firm market to book value measured by the book } \\
\text { value of total assets minus the book value of } \\
\text { common equity plus the market value of } \\
\text { common equity divided by the book value of } \\
\text { total assets. }\end{array}$ \\
\hline \multicolumn{3}{|c|}{ Governance Characteristics } \\
\hline BSIZE & Board Size & $\begin{array}{l}\text { Total number of directors on the board as at the } \\
\text { end of each year }\end{array}$ \\
\hline BIND & Board Independence & $\begin{array}{l}\text { Number of Independent directors / Total number } \\
\text { of directors }\end{array}$ \\
\hline \multirow{2}{*}{$\begin{array}{l}\text { ACSIZE } \\
\text { ACCOM }\end{array}$} & Audit committee Size & Numbers of members in audit committee. \\
\hline & Audit committee composition & $\begin{array}{l}\text { Total number of directors in audit committee / } \\
\text { Number of independent directors in audit } \\
\text { committee }\end{array}$ \\
\hline
\end{tabular}

\section{Results and discussion}

4.1 Impact of CG variables on ROA 


\begin{tabular}{|c|c|c|c|c|c|c|}
\hline \multicolumn{7}{|c|}{ ANOVA $^{b}$} \\
\hline \multicolumn{2}{|c|}{ Model } & \multirow{2}{*}{$\begin{array}{l}\text { Sum of Squares } \\
.114\end{array}$} & \multirow{2}{*}{$\begin{array}{l}\text { Df } \\
4\end{array}$} & \multirow{2}{*}{$\begin{array}{l}\text { Mean Square } \\
.029\end{array}$} & \multirow{2}{*}{\begin{tabular}{|l} 
\\
7.339
\end{tabular}} & \multirow{2}{*}{$\begin{array}{l}\text { Sig. } \\
.000^{\mathrm{a}}\end{array}$} \\
\hline \multirow[t]{3}{*}{1} & Regression & & & & & \\
\hline & Residual & 1.520 & 391 & .004 & & \\
\hline & Total & 1.634 & 395 & & & \\
\hline & tors: (Cons & , Audit Compc & ition, & Independenc & Ratio, & Size, \\
\hline
\end{tabular}

The ANOVA table is showing the association between the corporate governance variable identified in this study and the dependent variable ROA. As the $p$ value is 0.000 which is less than .05; thus, the result supports the hypothesis 1 that the corporate governance variables have positive impact on response variable ROA.

\begin{tabular}{|c|c|c|c|c|c|c|}
\hline \multicolumn{7}{|c|}{ Coefficients $^{\mathrm{a}}$} \\
\hline \multirow{2}{*}{\multicolumn{2}{|c|}{ Model }} & \multicolumn{2}{|c|}{$\begin{array}{l}\text { Unstandardized } \\
\text { Coefficients }\end{array}$} & \multirow{3}{*}{ 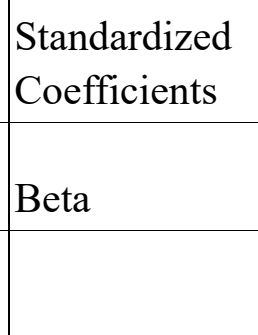 } & \multirow{3}{*}{$\begin{array}{l}\mathrm{t} \\
5.673\end{array}$} & \multirow{3}{*}{$\begin{array}{l}\text { Sig. } \\
.000\end{array}$} \\
\hline & & B & Std. Error & & & \\
\hline \multirow[t]{5}{*}{1} & (Constant) & .100 & .018 & & & \\
\hline & Board Size & -.003 & .001 & -.109 & -1.885 & .060 \\
\hline & $\begin{array}{l}\text { Board Independence } \\
\text { Ratio }\end{array}$ & .061 & .028 & .110 & 2.182 & .030 \\
\hline & Audit Committee & .011 & .004 & 164 & 2.776 & .006 \\
\hline & Audit Composition & .014 & .020 & 037 & .703 & .483 \\
\hline
\end{tabular}

The above table is showing the four explanatory variables, whether they are statistically significant and their impact on ROA. Board independence ratio and audit committee is statistically significant at $5 \%$ level of significance since the $\mathrm{p}$ values is less than 0.05 and 


\section{Macrothink}

have positive impact on ROA as reflected by positive coefficients (B). In addition to, P value of board size and audit composition is not statistically significant since its $p$ value is greater than 0.05. The negative coefficients of Board size indicates that the larger the size of board, the lesser the firm performance. Because, organizations having larger boards may face less effective control mechanisms due to weaker communication and indecisiveness of larger groups.

\subsection{Impact of CG variables on ROE}

\begin{tabular}{|c|c|c|c|c|c|c|}
\hline \multicolumn{7}{|c|}{ ANOVA $^{b}$} \\
\hline \multicolumn{2}{|c|}{ Model } & \multirow{2}{*}{$\begin{array}{l}\text { Sum of Squares } \\
.151\end{array}$} & \multirow{2}{*}{$\begin{array}{l}\text { Df } \\
4\end{array}$} & \multirow{2}{*}{$\begin{array}{l}\text { Mean Square } \\
.038\end{array}$} & \multirow{2}{*}{$\begin{array}{l}\text { F } \\
.933\end{array}$} & \multirow{2}{*}{$\begin{array}{l}\text { Sig. } \\
.444^{\mathrm{a}}\end{array}$} \\
\hline 2 & Regression & & & & & \\
\hline & Residual & 15.844 & 391 & .041 & & \\
\hline & Total & 15.995 & 395 & & & \\
\hline \multicolumn{7}{|c|}{$\begin{array}{l}\text { a. Predictors: (Constant), Audit Composition, Board Independence Ratio, Board Size, Audit } \\
\text { Committee }\end{array}$} \\
\hline
\end{tabular}

From the ANOVA table, the calculated $\mathrm{p}$ value is 0.15 which is greater than 0.05 ; thus the outcome does not support the hypothesis2. Hence, the result of the test signifies no association between the dependent variable ROE and the independent corporate governance variable. 


\begin{tabular}{|c|c|c|c|c|c|c|}
\hline \multicolumn{7}{|c|}{ Coefficients $^{\mathrm{a}}$} \\
\hline & & $\begin{array}{l}\text { Unsta } \\
\text { Coeff }\end{array}$ & & $\begin{array}{l}\text { Standardized } \\
\text { Coefficients }\end{array}$ & & \\
\hline \multicolumn{2}{|c|}{ Model } & B & Std. Error & Beta & $\mathrm{T}$ & Sig. \\
\hline \multirow[t]{5}{*}{2} & (Constant) & .186 & .057 & & 3.269 & .001 \\
\hline & Board Size & .001 & .004 & .014 & .241 & .810 \\
\hline & $\begin{array}{l}\text { Board Independence } \\
\text { Ratio }\end{array}$ & .086 & .090 & .049 & .950 & .343 \\
\hline & Audit Committee & .016 & .013 & .078 & 1.271 & .204 \\
\hline & Audit Composition & .076 & .063 & .066 & 1.197 & .232 \\
\hline
\end{tabular}

From the above table, it is found none of the above explanatory variable is statistically significant since $\mathrm{p}$ value is greater than 0.05 at $5 \%$ level of significance. But the positive coefficients reflect the positive direction of the above variables on firm performance as measured by ROE in this study.

4.3 Impact of CG variables on TQ

\begin{tabular}{|c|c|c|c|c|c|c|}
\hline \multicolumn{7}{|c|}{ ANOVA $^{\mathbf{b}}$} \\
\hline \multicolumn{2}{|c|}{ Model } & \multirow{2}{*}{$\begin{array}{l}\text { Sum of Squares } \\
4422.353\end{array}$} & \multirow{2}{*}{$\begin{array}{l}\text { Df } \\
4\end{array}$} & \multirow{2}{*}{$\begin{array}{l}\text { Mean Square } \\
1105.588\end{array}$} & \multirow{2}{*}{$\begin{array}{l}\mathrm{F} \\
7.184\end{array}$} & \multirow{2}{*}{$\begin{array}{l}\text { Sig. } \\
.000^{\mathrm{a}}\end{array}$} \\
\hline \multirow[t]{3}{*}{3} & Regression & & & & & \\
\hline & Residual & 60177.471 & 391 & 153.907 & & \\
\hline & Total & 64599.824 & 395 & & & \\
\hline & tors: (Cons & , Audit Compo & ition & Independence & Ratio, B & Size, \\
\hline
\end{tabular}




\section{Ml Macrothink}

Asian Journal of Finance \& Accounting

ISSN 1946-052X 2018, Vol. 10, No. 1

The ANOVA test result on depended variable (Tobin-Q) and independent variable (board size, board independence, size of audit committee and audit committee composition) is indicating that there is a significant relationship between Tobin-Q and corporate governance variables. As the $\mathrm{p}$ value is 0.000 which is less than .05 , thus, the test support the hypothesis and reveal that the corporate governance variables have positive impact on overvaluation of firm value in the security market.

\begin{tabular}{|c|c|c|c|c|c|c|}
\hline \multicolumn{7}{|c|}{ Coefficients $^{\mathrm{a}}$} \\
\hline \multirow{2}{*}{\multicolumn{2}{|c|}{ Model }} & \multicolumn{2}{|c|}{$\begin{array}{l}\text { Unstandardized } \\
\text { Coefficients }\end{array}$} & \multirow{2}{*}{\begin{tabular}{|l} 
Standardized \\
Coefficients
\end{tabular}} & \multirow[b]{2}{*}{$\mathrm{T}$} & \multirow[b]{2}{*}{ Sig. } \\
\hline & & B & Std. Error & & & \\
\hline \multirow[t]{5}{*}{1} & (Constant) & 20.662 & 3.498 & & 5.908 & .000 \\
\hline & Board Size & -.606 & .274 & -.128 & -2.214 & .027 \\
\hline & $\begin{array}{l}\text { Board Independence } \\
\text { Ratio }\end{array}$ & 14.461 & 5.545 & .131 & -2.608 & .009 \\
\hline & Audit Committee & 1.792 & .780 & .136 & -2.298 & .022 \\
\hline & Audit Composition & 11.901 & 3.898 & .162 & -3.053 & .002 \\
\hline
\end{tabular}

Since the $p$ values of all predictors are less than general acceptable limit 0.05 at $5 \%$ level of significance, all the explanatory variables are statistically significant and have impact on measurement of firm value in the securities market as measured by Tobin-Q in this study.

\section{Conclusion}

The issue of corporate governance has become essential in the present situation because of increasing fraudulent activities, agency conflicts and insider trading which weaken the corporate performance. Sound corporate governance gives assurance to the investor of providing transparent disclosure and relevant information that are investor-friendly. The study is mainly conducted to investigate the relationship between corporate governance and firm performance with taking into account of the role of board and audit committee. The sample size of the study is 81 listed companies containing from banking industry (30), financial institutions (23), fuel and power industry (18), IT sector (8) and telecommunication (2). Homogeneous purposive sampling has been used for the selection of sample size. Secondary data for the period of 5 years ranging from 2013 to 2017 has been taken into consideration for conducting the study. Conceptual Framework of the Anglo American Model is used in this 
research study. The multiple liner regression analysis is done as the underlying statistical test on the response variables, ROA, ROE and TQ to test the association between the explanatory variables (board size, board independence, size of audit committee and audit committee composition) with firm performance. The empirical findings of the study state that board independence ratio and audit committee is statistically significant and has positive impact on ROA and TQ. In the case of firm performance measure ROE, none of the explanatory variables considered in this research is statistically significant but has positive direction individually on ROE. Noticeably, board size is statistically insignificant and has negative correlation with ROA and TQ and small margin of positive correlation with ROE. It suggests that larger the board size, lesser the firm performance. Because, organizations having larger boards may face less effective control mechanisms due to weaker communication and indecisiveness of larger groups. The study is not beyond limitations. The study is conducted using a only four corporate governance variables and detruncating some other control mechanisms like ownership structure, board skills and management skills due to lack of availability of data. There is a scope of further research to explore the impact of corporate governance mechanisms in the contest of diverse social and environmental agency issues and their market valuations.

\section{References}

Abdul Rahman, R., \& Mohamed Ali, F. H. (2006). Board, audit committee, culture and earnings management: Malaysian evidence. Managerial Auditing Journal, 21(7), 783-804. https://doi.org/10.1108/02686900610680549

Ahmed, H. L., Alam, M. J., Jafar, S. A., \&Zaman, S. H. (2008). A Conceptual Review on Corporate Governance and its Effect on Firm's Performance: Bangladesh Perspective. AIUB Business and Economics Working Paper Series, 10, 1-24.

Andres, P., \& Vallelado, E. (2008). Corporate governance in banking: The role of the board of directors. Journal of Banking and Finance, 32, 2570-2580. https://doi.org/10.1016/j.jbankfin.2008.05.008

Armstrong, A., \& Sweeney, M. (2002). Corporate governance disclosure: Demonstrating corporate social responsibility through social reporting. New Academy Review, 1(2), 33-51.

Baysinger, B., \& Hoskisson, R. E. (1990). The composition of boards of directors and strategic control: Effects on corporate strategy. Academy of Management review, 15(1),

Bozec, R. (2005). Boards of Directors, Market Discipline and Firm Performance. Journal of Business Finance \& Accounting, 32(9-10), 1921-1960. https://doi.org/10.1111/j.0306-686X.2005.00652.x

Brickley, J.A., \& James, C.M. (1987). The takeover market, corporate board composition, and ownership structure: The case of banking. Journal of Law and Economics, 30, 161-181

Byrd, J., \& Hickman, K. (1992). The case for independent outside directors. Journal of Applied Corporate Finance, 5(3), 78-82. https://doi.org/10.1111/j.1745-6622.1992.tb00227.x 
Cremers, K. J., \& Nair, V. B. (2005). Governance mechanisms and equity prices. The Journal of Finance, 60(6), 2859-2894. https://doi.org/10.1111/j.1540-6261.2005.00819.x

Dey, D. K., \& Chauhan, Y. K. (2009). Board composition and performance in Indian firms: A comparison. IUP Journal of Corporate Governance, 8(2), 7.

Dhaliwal, D., Naiker, V., \& Navissi, F. (2006). Audit Committee financial expertise, Corporate Governance and Accruals Quality: An Empirical Analysis. Working Paper: University of Arizona (May).

Drobetz, W., Schillhofer, A., \& Zimmermann, H. (2003). Corporate governance and firm performance: Evidence from Germany. Basel, Switzerland: University of Basel. Mimeographed document. http://www. cofar. uni-mainz. De/dgf2003/paper/paper146. pdf.

Duchin, R., Matsusaka, J.G., \&Ozbas, O. (2010). When are outside directors effective? Journal of Financial Economics, 96(2), 195-214. https://doi.org/10.1016/j.jfineco.2009.12.004

Enobakhare, A. (2010). Corporate governance and bank performance in Nigeria. Diss. Stellenbosch: University of Stellenbosch.

Farber, D. B. (2005). Restoring trust after fraud: Does corporate governance matter? The Accounting Review, 80(2), 539-561. https://doi.org/10.2308/accr.2005.80.2.539

Gemmill, G., \& Thomas, D. C. (2004). Does governance affect the performance of closed-end funds?

Hermalin, B. E., \& Weisbach, M. S. (2001). Board of Directors as Endogenously Determined Institution: A Survey of the Literature. Economic Policy Review.

Jensen, M. C., \& Meckling, W. H. (1976). Theory of the firm: Managerial behavior, agency costs and ownership structure. Journal of financial economics, 3(4), 305-360. https://doi.org/10.1016/0304-405X(76)90026-X

Kajola S.O (2002): Corporate Governances and Firm Performance "Paper Presented at the Faculty Seminar of Faculty of Management Science”, Olabisi Onabanjo University

Kaplan, S. N. (1995). Corporate governance and incentives in German companies: Evidence from top executive turnover and firm performance. European Financial Management, 1(1), 23-36. https://doi.org/10.1111/j.1468-036X.1995.tb00004.x

Keasey, K., \& Wright, M. (1993). Issues in Corporate Accountability and Governance. Accounting and Business Research, 23(91a), 291-303. https://doi.org/10.1080/00014788.1993.9729897

Kirkpatrick, G. (2009). Corporate governance lessons from the financial crisis. OECD Journal: Financial Market Trends 2009/1, 1-30. https://doi.org/10.1787/fmt-v2009-art3-en

Kumar, N., \& Singh, J. (2012). Corporate governance in India: case for safeguarding minority shareholders rights. International journal of management \& business studies, 2(2). 


\section{Mll Macrothink}

Asian Journal of Finance \& Accounting

ISSN 1946-052X 2018, Vol. 10, No. 1

Metrick, A., \& J. Ishii. (2002). Firm level corporate governance. Global Corporate Governance Forum, Research Network

Moxey, P., \& Berendt, A. (2008). Corporate governance and the credit crunch. ACCA, London

Okiro, K., Aduda, J., \& Omoro, N. (2015). The Effect of Corporate Governance and Capital Structure on Performance of Firms Listed at the East African Community Securities Exchange. European Scientific Journal, ESJ, 11(7).

Ramano, G., Ferretti, P., \& Quirici, M. C. (2012). Corporate Governance and Efficiency of Italian Bank.

Shleifer,,A., \& Vishny, R. W. (1997). A survey of corporate governance. The Journal of Finance, 52, 737-783. https://doi.org/10.1111/j.1540-6261.1997.tb04820.x

Williams, R. S. (2002). Managing employee performance: Design and implementation in organizations. Cengage Learning EMEA.

Xie B, Davidson W N and Dadalt P J (2003). Earnings Management and Corporate Governance: The Roles of the Board and the Audit Committee. Working Paper, Southern Illinois University

Yige Ma, Kilgore A., \& Wright S. (2012). The Voluntary Formation of an Audit Committee”, 2012 Financial Markets and Corporate Governance Conference, available at http://ssrn.com/abstract $=1980484$

Zulkafli, A.H., \& Samad, F.A. (2007). Corporate governance and performance of banking firms: Evidence from Asian emerging markets. Advances in Financial Economics 12, 49-74. https://doi.org/10.1016/S1569-3732(07)12003-X 